\title{
Homocystinuria-Megaloblastic Anemia, cblE Complementation Type
}

National Cancer Institute

\section{Source}

National Cancer Institute. Homocystinuria-Megaloblastic Anemia, cble Complementation

Type. NCI Thesaurus. Code C142173.

An autosomal recessive condition caused by mutation(s) in the MTRR gene, encoding methionine synthase reductase. It is characterized by homocystinuria and megaloblastic anemia. 